\title{
Relasi Kuasa dalam Harmoni Budaya Jawa
}

\author{
Tegar Makmur \& Anastasia Yuni Widyaningrum* \\ Universitas Katolik Widya Mandala Surabaya \\ Jalan Dinoyo no. 42-44, Keputran, Tegalsari, Kota Surabaya, Jawa Timur 60265 \\ *e-mail : anastasia_widya@ukwms.ac.id
}

\begin{abstract}
The purpose of this study is to explore the concept of power relations in the video clip of the song Teman Hidup by singer Tulus. It becomes interesting when popular culture represents it in the work of the video clip of the song Teman Hidup by singer Tulus. The concepts used in the study in addition to an understanding of the culture of Javanese Yogyakarta, especially the life of the palace servants of Yogyakarta Palace, this study also uses the thinking of Stuart Hall, especially how the media represent social life that seems natural and full of harmony. In addition, concepts in cultural studies such as hegemony, ideology I patriarchy, and power relations. Using the Roland Barthes Semiotic method to be able to dismantle the ideology embedded in the research subject. The results showed that in the video clip of Friends of Life there is a power relation embedded in the video clip which denotatively displays the harmonization of Javanese culture. Thus, popular culture has increasingly strengthened power relations in society in Javanese culture
\end{abstract}

Keywords: Javanese culture, harmony, power relations, hegemony, ideology

\begin{abstract}
ABSTRAK
Tujuan penelitian ini adalah mengeksplorasi konsep relasi kuasa dalam video klip lagu Teman Hidup oleh penyanyi Tulus. Menjadi menarik ketika budaya popular merepresentasikannya dalam karya video klip lagu Teman Hidup oleh penyanyi Tulus. Konsep-konsep yang digunakan dalam penelitian selain pemahaman akan budaya Jawa Yogyakarta khususnya kehidupan abdi dalem Keraton Yogyakarta, penelitian ini juga menggunakan pemikiran Stuart Hall terutama bagaimana media merepresentasikan kehidupan social yang seolah tampak wajar dan penuh harmoni. Selain itu juga konsep-konsep dalam cultural studies seperti hegemoni, ideologl patriarki, dan relasi kuasa. Menggunakan metode Semiotik Roland Barthes untuk dapat membongkar ideologi yang tersemat dalam subjek penelitian. Hasil penelitian menunjukkan bahwa dalam video klip Teman Hidup ada relasi kuasa yang tersemat dalam video klip yang secara denotatif menampilkan harmonisasi budaya Jawa. Maka, budaya popular semakin mengukuhkan relasi kuasa dalam masyarakat dalam budaya Jawa.
\end{abstract}

Kata kunci: Budaya Jawa, harmoni, relasi kuasa, hegemoni, ideologi 


\section{Pendahuluan}

Yogyakarta dengan sejumlah kekhasan budayanya telah menjadi setting dari berbagai video klip. Citra Skolastika dengan lagu "Pasti Bisa" menggunakan setting Tugu Yogyakarta, Malioboro, dan bangunan khas Yogyakarta lainnya untuk memberi nuansa yang khas pada video klipnya. Begitu pula dengan adegan membatik bersama dengan seorang ibu memperkuat karakter budaya Jawa yang diangkat. Video klip yang lebih legendaris, lagu Kla-Project yang berjudul "Yogyakarta" memotret kehidupan kaum urban di Yogyakarta tahun 1990 an. Lagu ini menceritakan suasana Yogyakarta dengan berbagai kekhasannya seperti makanan, musisi jalanan, dan ramainya pedangang kaki lima.

Konsep video klip Kunci Hati menampilkan potongan-potongan kehidupan sehari-hari masyarakat Kota Gudeg (Priambodo, Mei 2016 ). Secara visual, video klip menampakkan latar belakang belakang bukit kapur dan kawasan yang nampaknya menunjukkan situasi daerah Kota Gede di Yogyakarta. Dalam video tersebut juga menampilkan adanya suatu pergelaran budaya mulai dari kirab budaya, tarian daerah, pertunjukan gamelan, sampai seni pantomim.

Setiap video klip di atas memiliki cerita masing-masing tentang Yogyakarta dengan berbagai kekhasannya. Video klip lagu Teman Hidup yang dibawakan oleh Tulus, menceritakan Yogyakarta dari sudut pandang perjalanan hidup (laku) dari keluarga abdi dalem di Keraton Yogyakarta.

Video klip yang dirilis tahun 2011 ini menonjolkan busana yang dikenakan oleh abdi dalem melalui pemakaian kain batik bermotif kawung, pakaian peranakan berbahan lurik, blangkon, selongsong (penutup keris), keris, dan pin dengan logo Keraton Yogyakarta. Kehidupan seorang abdi dalem baik dalam lingkungan Keraton maupun budaya Jawa secara tegas mengatur tentang hirarki. Dalam artikel "Batik Larangan Penguasa Mataram," dijelaskan bagaimana seorang abdi dalem bernama Mas Wedono Hardi menuturkan bahwa abdi dalem tidak pantas memadankan pakaiannya dengan pangeran oleh karena itu dirinya sering kali menegur abdi dalem yang tidak paham aturan larangan batik keraton, (Kurniawan, 2014)

Dalam budaya Jawa, hubungan kekuasaan diantara kedua jenis kelamin menempatkan wanita pada posisi yang subordinat, yaitu pihak yang dikuasai. Wanita sendiri secara sukarela menerima dan menyetujui kekuasaan laki-laki sebagai sesuatu yang wajar, (Handayani \& Novianto, 2005). Disinilah konsep hegemoni terjadi. Sebuah relasi kuasa tanpa paksaan dan pihak yang dikuasai menerima secara sukarela. (Handayani \& Novianto, 2005)

Secara kultural maupun ideologis, hegemoni beroperasi melalui institusiinstitusi masyarakat sipil meliputi institusi pendidikan, keluarga, gereja, media massa, dan budaya popular (Strinati, 2009). Konsep hegemoni mengandung pemahaman bahwa kelas tersebut berhasil membujuk kelas-kelas lain dalam masyarakat untuk menerima nilai-nilai moral, politik dan kulturalnya (Strinati, 2009)

Secara prinsip, sikap rukun melarang pengambilan posisi yang bisa menimbulkan konflik. Prinsip kerukunan tidak berarti bahwa orang Jawa tidak mempunyai kepentingan-kepentingan pribadi, melainkan suatu mekanisme sosial untuk mengintegrasikankepentingankepentingan demi kesejahteraan kelompok, (Suseno, 1984)

Dalam masyarakat berkembang nilainilai yang diperjuangkan oleh berbagai kelompok. Nilai-nilai tersebut seringkali 
ditangkap oleh media dan kemudian direproduksi ulang dalam berbagai karya yang menarik yang seringkali disebut sebagai budaya populer. Hal tersebut dijelaskan oleh Barker (Barker, 2014) bahwa budaya populer secara politis dianggap sebagai medan perjuangan untuk merebut makna atau dengan kata lain hegemoni budaya diperoleh atau dipertantangkan sehingga budaya populer berhubungan dengan isu klasifikasi dan kekuasaan. Sedangkan kepentingan pihak industri budaya dengan budaya masyarakat pengguna dijembatani oleh dengan semacam nilai-nilai tertentu dan hal tersebut diperlukan oleh individu atau kelompok masyarakat untuk melegitimasi kekuasaan, (Christomy \& Untung, 2004). Selanjutnya, media budaya yang berasal dari media massa dibangun karena keinginan dan kebutuhan suatu kelompok masyarakat, bangsa ataupun penguasademi kepentingan-kepentingan tertentu, (Christomy \& Untung, 2004).

Menurut Stuart Hall (Ida, 2014) dalam kajian budaya, praktek budaya mengkaji tentang bagaimana dunia atau kehidupan dimaknai dan bahasa digenerasikan melalui tanda-tanda yang terbentuk yang dihasilkan dalam sistem sosial.

Peneliti melihat bahwa video klip ini menampilkan budaya Jawa dari sudut pandang kehidupan abdi dalem. Sebagai seorang abdi dalem, identitas Keraton Yogyakarta melekat melalui berbagai atribut yang dikenakannya. Dengan naik sepeda ontel, abdi dalem melaksanakan aktivitasnya tanpa menggunakan alas kaki. Dari sinilah menarik bagaimana budaya Jawa dilihat dari sudut pandang dari abdi dalem dimana abdi dalem tidak bisa dilepaskan dari patronnya yaitu sistem di Keraton Yogyakarta. Menurut Barker (Ida, 2014) di sinilah konsep kekuasaan dimaknai dengan memperhatikan persoalan kelompok yang tersubordinasi melalui proses-proses Jurnal KOMUNIKATIF Vol. 8 No. 2 Desember 2019 sosial, tindakan sosial, dan hubungan yang terjadi.

Berdasarkan pemaparan diatas maka peneliti tertarik untuk mengeksplorasi bagaimana relasi kuasa dalam Budaya Jawa yang ditampilkan dalam produk budaya popular lagu Teman Hidup oleh Tulus.

\section{Kajian Pustaka}

a. Representasi Budaya

Dalam pemahaman teori kebudayaan, maka Geertz (Christomy \& Untung, 2004) menyampaikan kebudayaan sebagai gagasan semiotik dan interpretasi teks. Tanda (sign) dan teks ini diartikan sebagai rangkaian perilaku dan tindakan yang merupakan perilaku dan tindakan simbolis. Pandangan ini berbeda dengan pemahaman kebudayaan sebagai sistem kognitif, di mana kebudayaan tidak berada dalam batin manusia melainkan terbentuk dari para pelaku budaya

Tanda dan kode-kode kebudayaan tersebut terekam dalam media budaya yang dibentuk dari jaringan sistem radio, hasil reproduksi suara (kaset, CD), film, siaran televisi, dan media cetak seperti surat kabar dan majalah. Media budaya tersebut merupakan budaya yang membutuhkan imajinasi, suatu suara, kreativitas, dan kecanggihan teknologi. Dalam media budaya terkandung sesuatu "dibalik" unsur-unsur hakiki yang belum tersentuh dalam kajian lain (Christomy \& Untung, 2004)

Lebih jauh lagi, Stuart Hall (Ida, 2014) menjelaskan bahwa sentral dari studi media dan budaya adalah pada khalayak atau masyarakat yang selama ini kurang disentuh, terutama masyarakat yang membuat makna secara aktif dan masyarakat yang tidak dikooptasi oleh kepentingan-kepentingan kekuasaan (power interest) yang selama ini mendominasi media massa dan menentukan kehidupan sosial budaya 
masyarakat. Menurut Stuart Hall (Ida, 2014) kajian budaya atau dikenal dengan cultural studies adalah sebuah formasi diskursif yang menyatakan bahwa kajian budaya adalah sebuah kluster atau formasi, ide-ide, gambaran-gambaran (images) dan praktik-praktik yang menyediakan cara-cara untuk menyatakan, bentuk- bentuk pengetahuan, dan tindakan yang terkait topik tertentu, aktivitas sosial, atau institusi dalam masyarakat.

Salah Salah satu konsep penting dalam cultural studies adalah representasi. Representasi adalah produksi makna melalui bahasa. Dalam representasi, suatu konstruksi, tanda-tanda terorganisir menjadi bahasa dalam berbagai macam, (Hall, 1997)

Representasi menghubungkan makna dan bahasa terhadap budaya. Secara lebih lanjut, representasi adalah bagian esensial dari proses di mana makna diproduksi dan dipertukarkan diantara anggota-anggota dari sebuah budaya. Representasi juga melibatkan penggunaan bahasa, tandatanda, gambar-gambar yang mewakili atau merepresentasikan sesuatu, (Hall, 1997).

\section{b. Budaya Jawa dan Simbolisasi}

Penggunaan motif batik dijelaskan oleh Wibowo (Wibowo dkk, 1990) bahwa batik pada awalnya digunakan oleh raja dan abdi dalem di Yogyakarta sebagai tanda perangkat dan dalam konteks adati digunakan sebagai upacara. Batik tradisional merupakan batik yang dibuat berdasarkan pakem atau aturan yang berlaku. Pakem mengenai motif batik inilah menentukan status sosial atau tanda pangkat seseorang. Misalnya batik parang yang hanya digunakan oleh raja.

Selanjutnya, (Wibowo dkk, 1990) motif kain batik kawung berupa bulatan-bulatan yang menyerupai buah kawung (sejenis kelapa) yang ditata secara geometris. Pola geometris yang komposisinya rapi dan seimbang itu memiliki pusat yang diinterpretasikan sebagai raja atau pusat pemerintahan atau kekuasaan. Garis-garis dari motif ini menyerupai palang merupakan stilisasi dari buah kawung. Dalam filsafah orang Jawa, biji memiliki arti simbolik tersendiri sebagai lambang kesuburan (Wibowo dkk, 1990)

Di samping itu, pola kawung juga merupakan stitisasi bunga lotus atau teratai dengan keempat daun bunganya yang tengah merekah. Bunga lotus dalam arti simbolik merupakan lambang kesucian. Dalam kenyataannya, pohon lotus hidup di air keruh, tetapi bunganya tetap putih, bersih dan indah (Wibowo dkk,1990)

Simbolisme konteks kekuasaan menunjukkan keselarasan antara kerajaan dan jagat raya dapat dicapai dengan cara menyusun kerajaan sebagai jagat raya dalam bentuk kecil. Hal ini mengacu pada konsep spiritual yang berasal dari kultur India, yaitu kepercayaan, adanya kesejajaran antara makrokosmos dan mikrokosmos, antara jagat raya dan manusia. Dari kepercayaan ini, manusia berada di bawah kendali tenaga-tenaga yang bersumber dari mata angin, bintang dan planet sehingga hubungan diantara individu atau kelompok termasuk juga raja perlu menyeleraskan hubungan dan kegiatan mereka dengan jagat raya, (Rama, 2007).

Dalam struktur kerajaan Jawa dikenal konsep moncopat yang digunakan dalam tata politik, dan tata pemerintahan. Melalui konsep ini tata pemerintahan kerajaan Jawa digambarkan digambarkan sebagai empat lingkaran yang memiliki pusat yaitu empat lingkaran konsentris kerajaan Jawa, Keraton, negara (ibu kota), nagaraagung (ibu kota besar), dan manca nagara (negeri asing). Dalam Keraton yang dikepalai Sultan sebagai pusatnya. Dalam pemaknaannya, pusat kekuasaan yang 
dikelilingi empat bulatan, segi empat atau bintang-bintang diasosiasikan sebagai raja yang dikelilingi para pembantunyapembatunya yaitu para bupati yang terwujud dalam gambaran empat bulan segi empat atau bintang (Wibowo dkk, 1990).

c. Etika Jawa, dan Relasi Gender Pasangan Suami Istri

Secara garis besar ada dua prinsip yang dipegang oleh masyarakat Jawa demi tercapainya keharmonisan yang mana seseorang harus selalu melakukan olah rasa yang didukung oleh sikap batin yang tepat. Kedua prinsip yang dimaksud adalah prinsip rukun dan hormat. Menurut Magnis (Suseno, 1984) bahwa rukun adalah keadaan ideal yang diharapkan dapat dipertahankan dalam semua hubungan sosial, yang bertujuan menciptakan keselarasan sosial. Pada akhirnya tujuan utamanya adalah mencapai keselerasan sosial di mana semua pihak dalam kelompok berdamai satu sama lain. Oleh karena itu prinsip kerukunan menuntun masyarakat jawa untuk melakukan kontrol diri dan membawa diri dengan santun, tenang dan rukun.

Prinsip hormat menjelaskan tentang keteraturan secara hierarkis yang bernilai pada diri sendiri dan digunakan untuk membawa diri sesuai dengan keadaannya. Kesadaran dan kedudukan sosial diterapkan dalam kehidupan Jawa berupa panggilan yang membedakan antara junior dan senior. Geertz (Suseno, 1984) juga mengemukakan bahwa permulaan suatu pembicaraan merujuk pada tingkatan kehormatan yang harus ditunjukan sesuai dengan siapa seseorang berkomunikasi. Bahasa jawa yang terdiri dari krama dan ngoko memiliki penggunaan yang berbeda. Krama mengungkapkan sikap hormat, sedangkan ngoko mengungkapkan keakhraban.
Prinsip ini pada dasarnya hanya menuntut agar bentu-bentuk lahiriah pengakuan terhadap kedudukan setiap orang diperhatikan (Suseno, 1984)

Istilah wedi, isin, dan sungkan tampaknya menjadi gaya hidup dan karakteristik masyarakat Jawa. Wedi berarti adanya rasa takut baik secara fisik maupun batin akibat kurang adanya rasa tidak nyaman dari suatu tindakan. Isin berarti rasa malu atau juga bisa diartikan sedang merasa bersalah. Kemudian sungkan adalah bentuk dari rasa hormat yang sopan terhadap atasan atau sesama yang sudah dikenal atau belum dikenal. Ketiga karakteristik ini merupakan bentuk harmonisasi dari implementasi rukun dan hormat yang merupakan dua norma utama filsafat Jawa untuk mencapai keselarasan, (Suseno, 1984)

Kedua prinsip diatas bertujuan agar menciptakan keselarasan sosial. Keselarasan bukanlah prinsip moral, melainkan prinsip penata masyarakat. Prinsip tersebut melarang segala macam tindakan yang tidak sesuai dan menuntut konflik secara prinsipil untuk bisa dihindari dan hubungan-hubunga hierarkis yang selalu dihormati. Dengan demikian prinsip keselarasan merupakan suatu kerangka yang menjadi batas mutkak bagi segala apapun pada suatu tindakan. Secara prinsipil orang tidak boleh bertindak hanya berdasarkan penilaiannya sendiri terhadap sesuatu, melainkan harus melalui pertimbangan-pertimbangan moral melalui batasan rukun dan hormat (Suseno, 1984)

Keselarasan dalam budaya jawa juga muncul dalam relasi suami istri. Dalam budaya Jawa konsepsi paternalistik yang berkembang menempatkan istri sebagai konco wingking. Konsep paternalistik secara formal hadir untuk membagi peran antara laki-laki dan wanita. Oleh karena itu Padmo (Handayani \& Novianto, 2005) Dalam sistem pertalian darah yang Jurnal KOMUNIKATIF Vol. 8 No. 2 Desember 2019 
menganut asas bilateral yang dilihat dari nilai-nilai umum maupun adat kebiasaan khusus yang melembagakan nilai-nilai tersebut.

Selain itu dalam posisi kehormatan dalam mata pencaharian, sebisa mungkin perempuan Jawa tidak tampil dalam sektor publik karena secara normatif perempuan tidak boleh melebihi suami, (Handayani \& Novianto, 2005). Dalam konteks ini, istri harus selalu menghargai dan menghormati suami dan memenuhi segala kebutuhan dalam bentuk apapun termasuk kebutuhan birahi. Berkaitan dengan hal tersebut, perempuan Jawa sebenarnya memiliki sumbangsih yang sangat besar baik bagi suami, anak maupun keluarga. Posisi istri bisa dikatakan sebagai manajer kontrol yang membuatnya lebih kuat dari pada laki-laki.

Salah satu ciri kekuasaan wanita Jawa adalah kepasifan dan ketenangan yang tidak menunjukkan gejolak pemberontakan melainkan menunjukkan sifat kefeminitasnya. Dalam kultur yang menenkankan kelemahlembutan dan kehalusan maka kekuatan feminin menjadi tempat untuk berekspresi secara lebih leluasa. Wanita jawa tidak perlu menjadi maskulin untuk mendapat kekuasaan. Sifat feminin yang diperoleh dengan berperilaku halus dan pengendalian diri sehingga mampu meraih kekuasaan yang diperoleh dalam diam (tenang). Pengendalian diri ini merupakan ciri-ciri feminitas ketimbang aktif dan progresif (Handayani \& Novianto, 2005)

Pada akhirnya perempuan Jawa tetap memiliki otoritas pribadi, namun perempuan berusaha mencari cara agar kehendaknya dapat terpenuhi tanpa mengacaukan harmoni dengan keluar dari tatanan budaya. Oleh sebab itu pengabdian total yang dilakukan oleh perempuan merupakan bentuk strategi diplomasi untuk mendapatkan hak serta harapannya. Pengaruh perempuan dalam keluraga sangatlah besar bahkan seorang suami akan menjadi tergantung dengan istrinya terutama dalam sisi emosional. Sosok perempuan yang menjadi pengabdi dalam keluarga, merawat anak-anak, dan sifatnya yang kalem mampu menghipnotis laki-laki sehingga setiap langkah suami akan selalu dipengaruhi oleh istri (Handayani \& Novianto, 2005).

\section{Metode Penelitian}

Berdasarkan latar belakang maslah diatas maka Metode Semiotik model Barthes sesuai digunakan menjawab masalah dalam penelitian ini dikarenakan peneliti menduga ada nilai-nilai ideologis yang tersemat dalam teks. Penelitian ini menggunakan metode Semiotik Roland Barthes (Griffin, 2012) dengan sistem penandaan tiga langkah yaitu denotative sistem, konotatif system dan Mitos. Mitos disini dipahami sebagai ideology yang tersemat dalam produk produk budaya yang tidak disadari secara visual. Data didokumenatasikan dari video klip Lagu Teman Hidup oleh Tulus.

\section{Hasil dan Pembahasan}

a. Relasi Pasangan Suami Istri Dalam Budaya Jawa

Pada scene ini diawali dari kata "Kau jiwa yang selalu aku "Puja" memperlihatkan ungkapan cinta suami kepada istri. Lirik ini terdengar begitu agung karena kehadiran istri dalam rumah menjadi sangat berarti bagi suami. Ketika mendengar lirik tersebut, hati seorang istri dapat dengan mudah luluh. Kemudian hal tersebut berbalas ketika istri mengucapkan terima kasih kepada suami sambil mencium tangannya. Kata "terima kasih" di sini adalah untuk membalas budi suami atas segala kebaikan yang diberikan. Pada akhirnya dapat disimpulkan bahwa sebesar apapun rasa cinta suami kepada istri tetap saja istrilah yang harus terlebih dahulu tunduk dengan 
menghormati suami yang ditunjukkan lewat membukukkan badan, mencium tangan dan ucapan terima kasih.

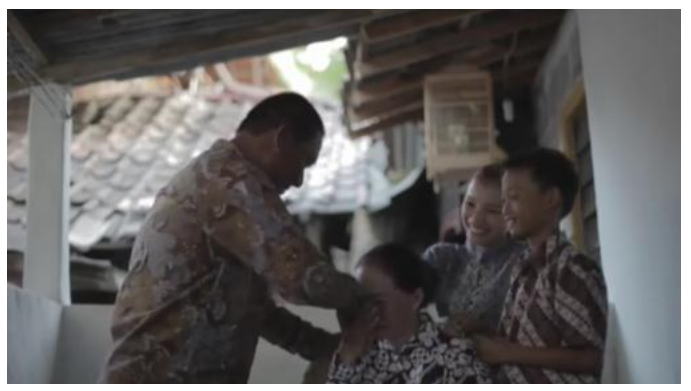

Gambar 1 Istri mencium tangan suami; Lirik "Terima Kasih Pak"

Sumber : Video Klip Teman Hidup Tulus (Scene 02:24)

Membungkukkan badan merupakan sebuah fenomena kultural dengan berbagai macam pemaknaan di dalamnya. Umat Islam seringkali membungkukan badan secara rutin ketika menjalankan sholat yang secara psikologis melambangkan adanya pengakuan pada yang Maha Kuasa. Dalam hubungan interpersonal, membungkukkan badan adalah ungkapan kesadaran kelas kepada pihak yang lebih tinggi posisinya atau lebih tua. Membungkukkan badan juga merupakan bentuk penghormatan dari yang muda kepada yang tua serta memenuhi sopan santun (Rachmadiana, 2004)

Dalam sejarahnya, dibanding dengan etnis lain, orang Jawa lebih mahir dalam membungkuk. Di Jawa, raja-raja menuntut banyak pada rakyatnya mulai dari membungkuk secara ekonomis (mengirim upeti), maupun secara biologis (Menyembah Ngarso Dalem Ingkang Sinuwun Baginda Raja). Budaya Jawa yang senantiasa menjaga keselerasan dan ketenangan tidak hanya dikondisikan dengan keadaan yang kondusif dan aman tetapi juga diungkapkan melalui perilaku individu yang sesuai dengan etika dan kesopanan (Rachmadiana, 2004)
Salah satu bentuk perilaku yang mencerminkan ketenangan adalah membungkukkan badan dan mencium tangan. Apabila membungkukkan badan dilakukan dengan menunduk, maka mencium tangan suatu gerakan dengan menghirup sesuatu (tangan) dengan hidung atau melekatkan hidung pada tangan. Baik membungkukkan badan maupun mencium tangan adalah cara untuk menjalin komunikasi dalam berinteraksi dengan sesama manusia yang tujuannya adalah untuk penghormatan dan ungkapan sopan santun kepada yang lebih tua atau lebih berkuasa. Ini merupakan etika dari budaya Jawa yang menentang sikap agresif dan keras, (Rachmadiana, 2004)

Implementasi dari prinsip tersebut akan menghasilkan pribadi Jawa yang tenang dan halus. Selaras dengan itu, maka video klip lagu "Teman Hidup" menggambarkan keselarasan sosial yang mampu terwujud ketika setiap pribadi menjalankan tugas sesuai dengan ranahnya. Ini terlihat ketika istri menjalankan perannya dalam sektor domestik dan suami dalam sektor publik serta dalam proses berpamitan seperti yang ditampakkan dalam video klip.

Ketika keselarasan sosial terwujud, menarik untuk dicermati karena perempuan atau istri justru secara sadar menerima, menyetujui struktur dan pembagian kerja tersebut. Pada tahap inilah, terjadi hegemoni yang menurut paparan Gramsci (Strinati, 2009) mengandung pemahaman bahwa kelas tersebut berhasil membujuk kelas-kelas lain dalam masyarakat untuk menerima nilai-nilai moral, politik dan kulturalnya.

Menurut Gramsci (Strinati, 2009), hegemoni sebagai sarana kultural maupun ideologis tempat kelompok-kelompok dominan dalam masyarakat melestarikan dominasinya dengan mengamankan "persetujuan spontan" kelompokkelompok subordinat, termasuk kelas 
pekerja, melalui penciptaan negosiasi konsensus politik maupun ideologis yang menyusup ke dalam kelompok-kelompok dominan maupun yang didominasi. Budaya dalam masyarakat dapat diinterpretasikan sebagai suatu hasil atau perwujudan hegemoni dari penerima "konsensual" oleh kelompok-kelompok subordinat atas nilai-nilai dan kepemimpinan kelompok dominan.

Dalam video klip, relasi pasangan suami istri menempatkan istri sebagai pihak yang terhegemoni oleh kekuasaan suami. Secara kultural, budaya Jawa dengan budaya patriarki yang kuat telah menciptakan struktur dengan pembagian peran antara suami dan istri yang telah disetujui serta dianggap sebagai sesuatu yang wajar baik oleh suami maupun istri. Pembagian peran ini secara turun temurun dilestarikan dan dikonsumsi oleh masyarakat, salah satunya lewat video klip sehingga melanggengkan kekuasaan suami dan tetap mensubordinasi istri.

Ketidaksetaraan dalam relasi pasangan suami istri terjadi karena budaya patriarki yang mengakar kuat. Dalam proses representasi yang merujuk pada video klip lagu "Teman Hidup" telah mengukuhkan dominasi suami terhadap istri sebagai pihak yang inferior atau berkuasa atas istri. Melalui ideologi, serangkaian makna diterima sebagai sesuatu wajar. Mengurus rumah tangga bagi istri dan bekerja di sektor publik bagi suami dianggap sebagai kodrat, padahal suami dan istri boleh dan bisa mengerjakan kedua peran tersebut. Belum lagi analogi kepercayaan swarga nunut, neraka katut akan semakin mengukuhkan bahwa istri akan tetap menjadi konco wingking.

Pembagian kerja telah menempatkan istri dalam posisi subordinat. Di sinilah terjadi hegemoni dalam relasi pasangan suami istri Jawa. Posisi subordinat atau menjadi pihak yang dikuasai telah melekat pada diri perempuan atau istri karena laki- laki atau suami memiliki penghasilan dari bekerja. Kenyataan ini membuat suami dianggap mempunyai tanggung jawab yang lebih besar karena sebagai penyedia kebutuhan hidup. Peran tersebut akhirnya membuat posisi tawar suami lebih menguntungkan dari pada istri.

Pengabdian atau pelayanan seorang istri secara total kepada suami telah menempatkan istri dipandang sebagai konco wingking yang artinya teman di dapur. Ada pula pemaknaan lain yang menyebut istri sebagai teman belakang, teman dalam mengelola rumah tangga, khususnya untuk memasak, mencuci, dan urusan anak-anak (Hermawati, 2007)

Lebih lanjut lagi menurut, prinsip di sebagian masyarakat tradisional Jawa menyebut bahwa swarga nunut, neraka katut (ke surga ikut, ke neraka juga ikut), Istilah ini seakan menunjukkan bahwa suami adalah penentu istri untuk masuk surga atau neraka. Apabila suami masuk surga, istri masuk surga, tetapi kalau suami masuk neraka, istri juga ikut masuk neraka walaupun istri banyak berbuat baik dan layak masuk surga. Prinsip ini semakin menunjukkan posisi lemah perempuan atau istri Jawa dibandingkan dengan lakilaki yang selalu mendapat posisi yang lebih terhormat.

Dalam sistem pertalian darah yang menganut asas bilateral yang dilihat dari nilai-nilai umum maupun adat kebiasaan khusus yang melembagakan nilai-nilai tersebut maka pandangan bahwa sistem bilateral justru tampak dalam praktik kehidupan sehari-hari. Seperti konsep garwa sebagai sigarining nyawa (belahan jiwa/separo dari jiwa) memberikan gambaran posisi yang lebih sejajar antara laki-laki dan perempuan. Perumpamaan ini lebih egaliter daripada kanca wingking. Suami dan istri adalah dua yang telah menjadi satu maka masing-masing adalah separo dari satu entitas, (Handayani \& Novianto, 2005). 
Konsep sigarining nyawa yang dianggap memberikan gambaran posisi yang sejajar nampaknya tidak terlihat dalam video klip "Teman Hidup." Dalam kehidupan sehari-hari, seorang istri tetap berada dalam kungkungannya, yaitu mengurus rumah tangga. Sebaliknya, suami dapat berkarir di luar untuk mencari nafkah.

Kenyataan ini sesuai dengan yang disampaikan oleh Abdullah (Hermawati, 2007) bahwa hingga saat ini, perempuan masih dianggap sebagai the second class atau "warga kelas dua" yang keberadaanya tidak begitu diperhitungkan. Implikasi dari konsep dan common sense ini tentang pemposisian yang tidak seimbang menjadi kekuatan di dalam pemisahan sektor kehidupan, di mana perempuan dianggap orang yang berkiprah di sektor domestik, sementara laki-laki berada di sektor publik. Ideologi semacam ini oleh berbagai pranata dan lembaga sosial telah disahkan, yang kemudian menjadi fakta sosial yang mengatur peran dan status yang dimainkan oleh perempuan.

Harmonisasi suami pada istri juga tampak dalam scene terakhir sebagai penutup video kilp dengan lirik "...kau jiwa yang selalu kupuja..." Dalam scene digambarkan bagaimana suami menyanyikan lirik tersebut pada istrinya kemudian ditutup dengan cium tangan istri kepada suami. Tampilan denotative memberikan kesan harmonisasi dalam relasi pasangan suami istri.

Kalimat lirik terdengar begitu agung karena kehadiran istri dalam rumah menjadi sangat berarti bagi suami. Ketika mendengar lirik tersebut, hati seorang istri dapat dengan mudah luluh. Kemudian hal tersebut berbalas ketika istri mengucapkan terima kasih kepada suami sambil mencium tangannya. Kata "terima kasih" di sini adalah untuk membalas budi suami atas segala kebaikan yang diberikan. Pada akhirnya dapat disimpulkan bahwa sebesar apapun rasa cinta suami kepada istri tetap saja istrilah yang harus terlebih dahulu tunduk dengan menghormati suami yang ditunjukkan lewat membukukkan badan, mencium tangan dan ucapan terima kasih.

Apa yang ditampilkan dalam video klip adalah bentuk keselarasan dan harmoni dalam kultur Jawa. Rachmadiana (Rachmadiana, 2004) menjelaskan hal tersebut bahwa dalam sejarahnya, dibanding dengan etnis lain, orang Jawa lebih mahir dalam membungkuk. Di Jawa, raja-raja menuntut banyak pada rakyatnya mulai dari membungkuk secara ekonomis (mengirim upeti), maupun secara biologis (Menyembah Ngarso Dalem Ingkang Sinuwun Baginda Raja). Budaya Jawa yang senantiasa menjaga keselerasan dan ketenangan tidak hanya dikondisikan dengan keadaan yang kondusif dan aman tetapi juga diungkapkan melalui perilaku individu yang sesuai dengan etika dan kesopanan.

Selanjutnya, Salah satu bentuk perilaku yang mencerminkan ketenangan adalah membungkukkan badan dan mencium tangan. Apabila membungkukkan badan dilakukan dengan menunduk, maka mencium tangan suatu gerakan dengan menghirup sesuatu (tangan) dengan hidung atau melekatkan hidung pada tangan. Baik membungkukkan badan maupun mencium tangan adalah cara untuk menjalin komunikasi dalam berinteraksi dengan sesama manusia yang tujuannya adalah untuk penghormatan dan ungkapan sopan santun kepada yang lebih tua atau lebih berkuasa. Ini merupakan etika dari budaya Jawa yang menentang sikap agresif dan keras, (Rachmadiana, 2004).

Lebih lanjut, istilah wedi, isin, dan sungkan tampaknya menjadi gaya hidup dan karakteristik masyarakat Jawa. Wedi berarti adanya rasa takut baik secara fisik 
maupun batin akibat kurang adanya rasa tidak nyaman dari suatu tindakan. Isin berarti rasa malu atau juga bisa diartikan sedang merasa bersalah. Kemudian sungkan adalah bentuk dari rasa hormat yang sopan terhadap atasan atau sesama yang sudah dikenal atau belum dikenal. Ketiga karakteristik ini merupakan bentuk harmonisasi dari implementasi rukun dan hormat yang merupakan dua norma utama filsafat Jawa untuk mencapai keselarasan, (Suseno, 1984).

Ketika keselarasan sosial terwujud, menarik untuk dicermati karena perempuan atau istri justru secara sadar menerima, menyetujui struktur dan pembagian kerja tersebut. Pada tahap inilah, terjadi hegemoni yang menurut paparan Gramsci (Strinati, 2009) mengandung pemahaman bahwa kelas tersebut berhasil membujuk kelas-kelas lain dalam masyarakat untuk menerima nilai-nilai moral, politik dan kulturalnya.

Menurut Gramsci, hegemoni sebagai sarana kultural maupun ideologis tempat kelompok-kelompok dominan dalam masyarakat melestarikan dominasinya dengan mengamankan "persetujuan spontan" kelompok-kelompok subordinat, termasuk kelas pekerja, melalui penciptaan negosiasi konsensus politik maupun ideologis yang menyusup ke dalam kelompok-kelompok dominan maupun yang didominasi. Budaya dalam masyarakat dapat diinterpretasikan sebagai suatu hasil atau perwujudan hegemoni dari penerima "konsensual" oleh kelompok-kelompok subordinat atas nilai-nilai dan kepemimpinan kelompok dominan tersebut, (Strinati, 2009).

Dalam video klip, relasi pasangan suami istri menempatkan istri sebagai pihak yang terhegemoni oleh kekuasaan suami. Secara kultural, budaya Jawa dengan budaya patriarki yang kuat telah menciptakan struktur dengan pembagian peran antara suami dan istri yang telah disetujui serta dianggap sebagai sesuatu yang wajar baik oleh suami maupun istri. Pembagian peran ini secara turun temurun dilestarikan dan dikonsumsi oleh masyarakat, salah satunya lewat video klip sehingga melanggengkan kekuasaan suami dan tetap mensubordinasi istri.

Gramsci juga memandang bahwa hegemoni sebagai salah satu aspek kontrol sosial yang muncul dari konflik sosial. Hegemoni juga merupakan sekumpulan gagasan konsensual yang berada dan membentuk kelas maupun konflik-konflik sosial lainnya (Strinati, 2009). Dalam budaya Jawa, prinsip yang menjunjung tinggi keselarasan sosial nampaknya akan semakin melanggengkan kekuasaan suami. Ketika konflik kelas antara suami dan istri yang telah dikemukakan oleh Gramsci tidak disadari baik oleh suami maupun istri dan hegemoni sebagai kontrol sosial diterima oleh masyarakat Jawa untuk menghormati hierarki. Sebagaimana yang sudah dijelaskan oleh Magnis Suseno (Suseno, 1984) (Goode, 2002)bahwa keselarasan sosial melarang segala tindakan yang tidak sesuai dan menuntut konflik secara prinsipil untuk bisa dihindari dan hubungan-hubungan hierarki harus selalu dihormati.

Ketidaksetaraan dalam relasi pasangan suami istri terjadi karena budaya patriarki yang mengakar kuat. Dalam proses representasi yang merujuk pada video klip lagu "Teman Hidup" telah mengukuhkan dominasi suami sebagai pihak yang inferior atau berkuasa atas istri. Melalui ideologi, serangkaian makna diterima sebagai sesuatu wajar. Mengurus rumah tangga bagi istri dan bekerja di sektor publik bagi suami dianggap sebagai kodrat, padahal suami dan istri boleh dan bisa mengerjakan kedua peran tersebut. Belum lagi analogi kepercayaan swarga nunut, neraka katut akan semakin mengukuhkan bahwa istri akan tetap menjadi konco wingking. 
Dengan demikian, mitos yang muncul adalah bahwa budaya patriarki yang dianut sebagian masyarakat Jawa menempatkan suami pada posisi superior dan istri inferior. Dalam video klip lagu "Teman Hidup" telah terjadi hegemoni yang diterima begitu saja oleh istri sebagai pihak yang tersubordinat oleh suami berdasarkan dari kedudukan istri dalam relasi pasangan suami istri.

Berdasarkan paparan analisis di atas, maka relasi pasangan suami istri dalam budaya Jawa telah menciptakan struktur sosial, di mana suami berada pada posisi superior dan istri inferior. Bagi orang Jawa, menjadi konco wingking bukan berarti kalah atau menjadi inferior. Bekerja di sektor domestik, menundukan kepala dan mencium tangan suami adalah suatu pengabdian dan bukan sebuah keterpaksaan. Ketika suami berada di sektor publik, seorang istri hadir dari belakang dengan berada di rumah untuk mendorong atau bekerja di balik layar sehingga pada akhirnya berperan besar dalam kesuksesan suami. Dengan demikian, mitos yang muncul adalah bahwa budaya patriarki yang dianut sebagian masyarakat Jawa menempatkan suami pada posisi superior dan istri inferior.

\section{b. Keluarga Jawa}

Sub bab "Keluarga Jawa" berisi analisis tentang kehidupan keluarga Jawa. Sub bab ini akan berbeda dengan pembahasan sebelumnya karena berfokus pada keluarga yang terdiri dari ayah, ibu dan anak. Menjadi penting untuk dianalisis karena dalam keluarga telah terjadi sekatsekat hubungan yang terlihat dalam kedudukan setiap anggota keluarga terutama pada sosok ibu.

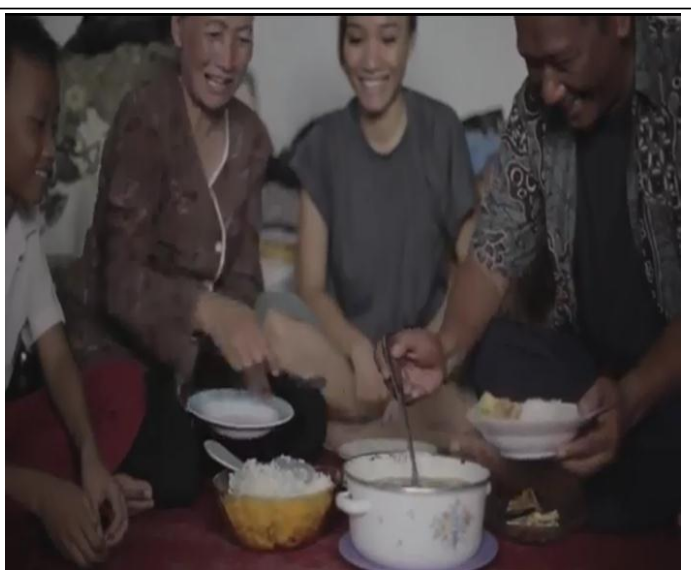

Gambar 1 Lirik : "Berdua Kita Hadapi Dunia" Scene 03:08

Sumber : Video Klip Teman Hidup Tulus

(Scene 02:24)

Scene pada gambar 2 menunjukkan mereka makan dengan nasi dan satu lauk yaitu sup yang berada di sebuah panci. Saat itu, terlihat seorang laki-laki yang sudah memegang piring berisi nasi, dan hendak mengambil sup yang ada di panci berwarna putih. Ketika itu, perempuan yang mengenakan pakaian berwarna cokelat dan kedua orang yang berada di sebelahnya belum mengambil makan. Tampak pula, perempuan itu sedang mengambil piring untuk kedua orang di sebelahnya. Tangan kiri memegang piring, dan tangan kanan memegang sendok.

Perempuan yang memegang piring dan sendok adalah ibu, laki-laki yang sedang bersiap makan adalah ayah, dan kedua orang yang berada di sebelah ibu adalah anak. Ayah, ibu dan kedua anaknya makan dengan gembira sebagai satu keluarga. Suasana gembira di dalam rumah itu terlihat dari senyuman di wajah mereka berempat.

Gambaran tentang keluarga Jawa dan deferensi peranan yang terjadi dalam keluarga terlihat dalam scene, ketika ayah sudah siap menyantap makanan dengan memegang piring yang berisi nasi, ibu masih melayani kedua anaknya dengan mengambilkan piring dan sedok. Pekerjaan ibu di dalam rumah sebenarnya 
sangat kompleks, mulai dari mempersiapkan kebutuhan suami untuk berangkat kerja, mengurus anak, memasak, mengambil jemuran (pakaian), merapikan pakaian, dan pekerjaan lain dilakukan secara simultan dari pagi hingga malam. Berbeda halnya dengan suami yang bekerja di luar, namun ketika berada di rumah, la mendapat pelayanan dari seorang istri.

Pembagian pekerjaan terutama dalam ranah domestik sebenarnya dapat dilakukan oleh laki-laki, tetapi tidak dilakukannya, padahal pekerjaan yang khusus dilakukan laki-laki biasanya tidak menuntut seluruh waktunya. Hal itu senada dengan pernyataan William J Goode (Goode, 2002) bahwa pembagian pekerjaan tidak didasarkan atas dasar biologis. Satu faktor yang dianggap penting olehnya adalah kedudukan suami atau kedudukan laki-laki dalam masyarakat apapun tugas khususnya akan dianggap lebih terhormat.

Dari pernyataan tersebut, maka apa yang tergambar mengenai seorang ibu dapat dikatakan sebagai pribadi yang "sudah Jawa," di mana memiliki kepekaan rasa yang tinggi sebagai sebuah implikasi praktis dari upaya pendalaman rasa secara terus menerus, yaitu penaklukan diri ke dalam dunia batin. Oleh karena itu, kontak batin ibu terhadap anak atau suami sangat besar. Adapun sifat feminin lain dari seorang ibu adalah kesediaan untuk menderita bagi orang lain, mudah melakukan penaklukan diri dan menghaluskan rasa secara terus menerus. Dalam kondisi tersebut, pikiran dan hatinya menjadi jernih karena terbebas dari kepentingannya sendiri sehingga ibu semakin bersedia sabar, tenang, dan semakin tampak halus, (Handayani \& Novianto, 2005). (Siswanto, 2010)

Prinsip mangan ora mangan waton kumpul (biar makan atau tidak amakan asal kumpul) tepat untuk menggambarkan kehidupan keluarga Jawa yang selalu mendorong persatuan. Ini didasarkan dari prinsip moral yang berhubungan dengan keberadaan pemimpin yang didukung oleh sistem pendidikan keluarga, di mana orang tidak dapat berdiri sendiri dan selalu membutuhkan pertolongan dan bimbingan dalam memecahkan masalah. Oleh karena itu, orang Jawa hormat, taat dan lebih senang dengan pendapat pemimpin mereka. Ini bukan merupakan suatu keterpaksaan melainkan karena kepercayaan kepada orang terlebih dari kharisma dan pangkat yang lebih penting dari pada minat mereka terhadap cita-cita atau prestasi (Siswanto, 2010).

Kultur Jawa dan konsep kekuasaan yang menekankan kelemahlembutan dan kehalusan membuat sisi feminin menemukan tempatnya untuk mengekspresikan diri secara lebih leluasa (Handayani \& Novianto, 2005). Dari sikap ini, maka istri atau ibu hadir untuk melayani keluarga dengan berada di ruang domestik untuk melakukan berbagai kegiatan rumah tangga. Secara sadar, la membimbing, melayani, mengontrol, mengalah, memberikan afeksi (kasih sayang) kepada anak-anak dan memenuhi segala tuntutan suami yang merupakan kepala dalam rumah tangga. Pada akhirnya, sifat feminim yang dimiliki oleh ibu atau istri adalah untuk kepentingan bersama yaitu memenuhi kebutuhan suami dan anak.

Dalam video klip, penghormatan terhadap hierarki tidak tampak dalam tataran bahasan maupun panggilan antara junior dan senior. Penghormatan dalam rumah yang terlihat adalah proses berpamitan antara suami dan istri serta suasana dalam makan. Dalam scene terlihat ayah terlebih dahulu makan dibandingkan dengan anak dan ibunya. Sebelumnya, istri terlebih dahulu mengambilkan nasi untuk suaminya. Setelah itu, ibu justru melayani anak- 
anaknya dengan mengambilkan piring dan sendok. Dalam scene ini terlihat siapa yang melayani, dan dilayani, siapa yang pertama menyantap makanan, dan siapa yang terakhir menyantap makanan. Ibu sebagai orang yang melayani semua anggota keluarga dan yang terakhir makan atau hanya mendapat sisa-sisa, sedangkan ayah yang dilayani dan yang pertama makan.

Dalam keluarga Jawa, pangkal pokok dari semuanya adalah hormat. Pengertian ini begitu istimewa bagi orang Jawa sehingga tidak dapat dengan mudah dialihbahasakan. Hormat mengandung makna yang kompleks, yang sedikit memiliki pertautan dengan "respect." Tindakan penghormatan sebenarnya tidaklah digugah oleh diri sendiri atau individu melainkan karena kedudukannya. Tidak seperti di Barat, "respect" tidak harus merujuk dengan sikap terhadap seseorang yang mempunyai kekuasaan tinggi. Dalam hubungannya dengan keluarga Jawa, ibu menunjukkan otoritas yang sebenarnya, tetapi ayahlah yang menerima respect itu. Dalam hubungannya dengan kemasyarakatan orang Jawa bahwa aspek penting yang sebenarnya adalah bukan karena ketulusan perbuatannya, tetapi keberhasilan seseorang di dalam menyembunyikan segala aspek yang bertentangan di dalam hubungan tersebut (Geertz, 1883).

Dalam kaitannya dengan visualisasi video klip, maka etika Jawa yang dihayati oleh orang Jawa untuk mencapai keselarasan sosial atau harmoni seakan tidak mampu membongkar kedok dalam hubungan keluarga. Prinsip ini pada dasarnya baik karena mampu menciptakan keharmonisan dan keseimbangan, namun di sisi lain prinsip ini mengajarkan untuk selalu bersikap pasrah terhadap segala sesuatu yang diterima. Kompeksitas pekerjaan ibu seakan tidak mampu membuatnya naik kelas atau menerima penghormatan sama sebagaimana yang diterima oleh suaminya.

Kebersamaan sebagai keluarga lewat makan yang disertai dengan lirik "Berdua Kita hadapi dunia" barangkali merupakan bujuk rayuan yang berhasil mengalihkan masalah ketidaksetaraan dalam keluarga dengan kebersamaan. Apa yang terlihat dari scene tersebut telah memperlihatkan kedudukan seorang laki-laki atau ayah lebih tinggi dalam keluarga sehingga menjadi sangat dilayani sekaligus dihormati. Berbeda dengan ibu yang kedudukannya berada di bawah ayah, namun masih menunjukkan sikap melayani kepada anak-anaknya. Itu tak lepas dari sikap feminim seorang ibu yang sabar, tenang dan halus serta bersedia menderita bagi orang lain termasuk anak dan suaminya.

Dalam beberapa literatur disebutkan bahwa dalam kultur Jawa sosok ibu dihormati lebih dari segalanya. Baik anak laki-laki, anak perempuan, dan suami akan mendapat perlindungan dan kontrol dari ibu, dari rumah. Kenyataan ini mengacu bahwa ibu sebagai simbol moralitas, maupun sebagai pusat rumah yang selalu dipercaya. Posisi ini tidak dimiliki oleh bapak yang menjadi simbol dunia luar, (Handayani \& Novianto, 2005). Kekuatan wanita Jawa tidak dirasakan sebagai ancaman atau pun kekerasan baik bagi suami maupun masyarakat luas, tetapi justru sebaliknya kekuatannya selalu dirasakan orang lain sebagai kelembutan, kehangatan, kesabaran, dan penuh pengertian. Hingga pada akhirnya suamilah yang justru tergantung kepada istri terutama secara emosional, entah disadari atau tidak, disukai ataupun tidak oleh pihak suami (Handayani dan Novianto, 2005 : 202).

Dari sini, maka mitos yang terbentuk adalah bahwa pernyataan dari teori yang menyebut ibu sebagai pusat rumah dan 
simbol moralitas nampaknya hanya sekadar ungkapan yang justru mensubordinasi sekaligus mengukuhkan peran ibu yang hanya memusatkan perhatiannya di rumah dan sekali lagi tugasnya adalah melayani dengan segudang pekerjaannya. Ibu sebagai pusat rumah tidak sepenuhnya merdeka karena harus tunduk kepada suami, termasuk dalam soal makan bersama keluarga, di mana ibu akan melayani suami dan anaknya terlebih dahulu. Sosok ibu yang dihormati lebih dari segalanya pada akhirnya tetap akan kalah karena terlebih dahulu harus tunduk dan melayani suami terlebih dahulu, (Handayani \& Novianto, 2005).

Berdasarkan paparan analisis di atas, maka budaya Jawa yang tergambarkan dalam video klip lagu "Teman Hidup" telah menciptakan hierarki dalam keluarga, di mana ayah selalu dilayani dan dihormati karena kedudukannya lebih tinggi dibandingkan dengan ibu yang harus melayani dan menghormati. Dalam budaya Jawa, pelayanan seorang ibu dalam keluarga justru dirasakan sebagai kekuatan. Merujuk pada video klip, pelayanan tersebut memperlihatkan kebahagiaan dari seorang istri yang berhasil melayani keluarganya.

c. Keraton Yogyakarta di Mata Abdi Dalem

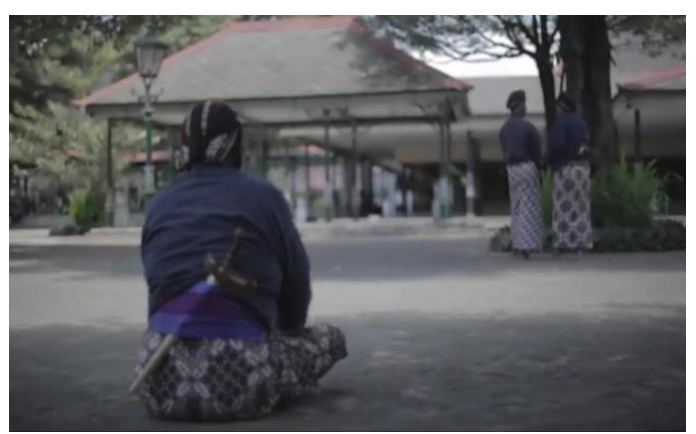

Gambar 2 Tiga abdi dalem yang berada di Pelataran Kedhaton

Sumber : Video Klip Teman Hidup Tulus

(Scene 02:24)
Video klip berlokasi di Keraton Yogyakarta, tepatnya di pelataran kedhaton terdapat tiga laki-laki yang tak lain adalah abdi dalem. Suasana sepi terlihat di pelataran tersebut dengan salah seorang abdi dalem berada pada posisi duduk bersilah sambil memandang sebuah bangunan megah di depannya, yaitu Bangsal Kencono. Kondisi berbeda terlihat dari dua abdi dalem lain yang berada lebih dekat dengan Bangsal Kencono. Mereka berada tepat di depan pohon sawo kecik dan keduanya tampak berdiri dengan posisi agak berhadapan.

Keraton Yogyakarta tidak hanya menjadi tempat bagi raja untuk tinggal, melainkan juga sebagai pusat kerajaan, pusat politik, dan di masa sekarang lebih banyak difungsikan sebagai pusat kebudayaan Jawa. Moedjanto (Moedjanto, 1994) bahwa Daerah Istimewa Yogyakarta dengan Keraton Yogyakarta memiliki peran penting baik sebagai pusat pemerintahan dan kebudayaan. Perkembangan teknologi komunikasi yang cepat berdampak pada berbagai dimensi dalam kehidupan manusia termasuk pada Keraton. Pergeseran fungsi keraton Yogyakarta dari pusat seluruh kehidupan dengan politik sebagai faktor yang dominan menjadi pusat kebudayaan. Keraton sebagai produk budaya masa lampau adalah pelopor modernisasi dalam segala hal. Termasuk dalam pemerintahan, demokrasi, penyederhanaan dan keterbukaan upacara.

Dalam kepercayaan masyarakat Jawa, pembicaraan mengenai raja dan kekuasaan tidak dapat dipisahkan dari konsep budaya India, yaitu kepercayaan adanya kesejajaran antara makrokosmos dan mikrokosmos, antara jagat raya dan dunia manusia. Kepercayaan ini membuat manusia berada di bawah kendali tenagatenaga yang bersumber pada arah mata angin, bintang-bintang, dan planet-planet. 
Tenaga ini dapat menghasilkan kemakmuran, tetapi di sisi lain dapat membawa kehancuran, (Rama, 2007)

Implementasi dari kultur tersebut tercermin dari bangunan Keraton Yogyakarta yang ditata berdasarkan wawasan integral makro dan mikrokosmologis. Kawasan Keraton yang membentang merupakan kesatuan kosmologis AUM (Agni/Gunung Merapi, Udaka/Laut Selatan, Maruta/udara bebas atau segar, di atas Sitilnggil, yaitu tanah yang ditinggikan sebagai pengejawentahan akan harkat manusia atas perkenaan Tuhan YME, diangkat dan ditinggikan sebagai Kalifatul-Lah, (Rama, 2007)

Dalam keraton sendiri ada dua poros yakni sisi barat-timur yang merupakan ruang pribadi, akhrab dan keramat, dan sisi utara-selatan yang berfungsi untuk ruang umum, resmi, dan upacara. Sepanjang utara-selatan meliputi (1) Alunalun Utara, (2) Sitihinggil Utara, (3) Kemandhungan Utara, (4) Srimanganti, (5) Kedhaton, (6) Kema-gangan, (7) Kemandhungan Selatan, (8) Sitihinggil Selatan, dan (9) Alun-alun Selatan. Pelataran kedhaton menjadi puncak konstelasi dari sembilan pelataran tersebut. Pelataran ini diapit pula oleh dua pelataran domestik (kesatriyan di sisi timur dan keputren di sisi barat ) tempat keluarga keraton tinggal (Wardani, 2011)

Makna konstelasi dapat dimaknai sebagai inti dari kompleks keraton yang posisinya berada di tengah sehingga mampu memberikan energi ke segala penjuru. Dari pengamatan peneliti, bahwa area pelataran kedhaton keseluruhan merupakan halaman dengan hamparan pasir yang di beberapa sisinya terdapat pohon sawo kecik yang berfungsi sebagai penangkal petir. Walaupun pelataran ini terbuka, namun ruangan-ruangan di sekitar pelataran ini bersifat privat, artinya tidak boleh sembarangan orang masuk.
Dalam kepercayaan Hindu, bangunan joglo mengacu pada bentuk meru (Mahameru), yakni bentuk atap yang menjulang tinggi pada bagian tengah dan disebut dengan atap brunjung. Prinsip kosmologi dari bangunan ini bahwa dunia terbagi dalam tiga lapisan yang disebut dengan Triloka, yakni Jagad atas, Jagad tengah, Jagad bawah. Jagad atas merupakan tempat bersemayamnya para dewa dan supreme being, jagad tengah adalah alam dunia, tempat tinggal para manusia serta segala makhluk yang berbadan jasmani, sedangkan jagad bawah mewakili kekuatan-kekuatan jahat di alam, (Wardani, 2011)

Abdi dalem terbagi menjadi dua yaitu abdi dalem keprajan dan abdi dalem punakawan. Abdi dalem keprajan merupakan pegawai pemerintah yang masih aktif maupun sudah pensiun, termasuk TNI/Polri yang mendaftarkan diri sebagai abdi dalem. Kewajiban mereka adalah sowan bekti dengan sungkeman saat Hari Raya Idul Fitri. Abdi dalem ini juga tidak mendapat kekucah (gaji) karena telah mendapatkan gaji dan uang pensiun dari pemerintahan.

Sedangkan abdi dalem punakawan adalah abdi dalem yang bertugas di keraton. Abdi dalem punakawan sendiri dibagi lagi menjadi dua, yaitu bertugas di tepas (kantor keraton) tiap jam kerja atau harian. Satu lagi, caos yang merupakan abdi dalem yang tidak diwajibkan masuk setiap hari. Abdi dalem punakawan sendiri berhak menerima kekucah (gaji) dan honor dari dana keistimewaan (Rudiana., 2016).

Walaupun keprajan dan punakawan berbeda tugas dan tanggung jawab namun kedua abdi dalem ini memiliki tingkatan pangkat yang sama. Sebelum diangkat menjadi abdi dalem, mereka menjalani magang selama dua tahun. Setelah itu, barulah menyandang pangkat dari yang terendah yaitu Jajar, Bekel Anom, Bekel Sepuh, Lurah, Penewu, Wedana, Riyo 146 
Bupati, Bupati Anom, Bupati Sepuh, Bupati Kliwon, Bupati Nayoko, dan Pangeran Sentana. Kenaikan pangkat dipertimbangkan dari presensi, dan keahlian. Lama waktu dalam setiap kenaikan pangkat berkisar tiga tahun atau lebih. Di samping itu, dalam menjalankan tugas, sepanjang masih sehat dan mampu melaksanakan tugas keraton sehari-hari, meskipun berusia lanjut maka tidak ada batasan usia untuk menentukan waktu miji atau pensiun (Rudiana, 2016)

Secara visual, video klip ini memperlihatkan budaya Jawa dari sudut pandang kehidupan abdi dalem punakawan yang hanyalah warga biasa. Abdi dalem tersebut membutuhkan waktu yang sangat lama untuk bisa naik pangkat menjadi bupati anom. Berbeda dengan penjabat yang nampaknya terlihat lebih mudah mendapat gelar KRT karena mungkin dianggap lebih berjasa dengan gelar dan kepangkatan yang dimilikinya. Dalam scene tersebut, ketiga abdi dalem hanya bisa memandang Bangsal Kencono karena setinggi apapun posisi pangkat mereka, misalnya berpangkat bupati anom dan bergelar Kanjeng Mas Tumenggung, namun tetap saja tidak bisa masuk karena hanya Kanjeng Raden Tumenggung (KRT) yang masih diperbolehkan menginjakan kaki pada bangsal tersebut. Perbedaan lain terlihat dalam hal gaji, di mana abdi dalem keprajan mendapat penghasilan yang jauh lebih besar dibandingkan dengan punakawan.

Pada akhirnya, bangunan Keraton Yogyakarta yang begitu kompleks dan kepercayaan pada energi makrokosmos dan mikrokosmos membuat Keraton Yogyakarta begitu mempertahankan kelanggengan budayanya. Jenjang hierarki dapat ditemui dari berbagai simbol-simbol termasuk dalam bangunan. Penjelasan tersebut seakan mengukuhkan bahwa abdi dalem hanya sebatas berada di sekitar pelataran kedhaton dan secara hierarki dianggap tidak ada. Itu tercermin dalam pemaknaan bangunan joglo karena urutan ketiga hanya untuk segelintir abdi dalem yang memiliki gelar Kanjeng Raden Tumenggung (KRT).

Hierarki dalam budaya Jawa menyebabkan abdi dalem berada pada posisi bawah atau lebih rendah sehingga menjadi pihak yang dikuasai. Kenyataan ini lantas tetap membuat abdi dalem loyal terhadap Keraton dan Raja. Lirik dari scene "Bersama Arungi Derasnya Waktu" adalah sebuah ajakan dari Keraton Yogyakarta kepada abdi dalem untuk terus menjaga kelestarian budaya Jawa. Hingga kini denyut kehidupan keraton tetap terjaga, salah satunya karena jasa dari para abdi dalem.

Pengabdian abdi dalem terutama yang berasal dari rakyat biasa menimbulkan segelintir pertanyaan. Gaji kecil dan segala aturan yang cenderung mensubordinasi abdi dalem justru diterima sebagai sesuatu yang wajar karena keyakinan akan mendapat berkah dari Tuhan dengan mengabdi pada Keraton. Dikutip dari Kompas (Kurniawan, 2014) salah satu abdi dalem bernama Mudiyono menceritakan bahwa gaji yang diterima saat masih berpangkat jajar sebesar Rp 1750 per bulan. Setelah 34 tahun mengabdi dan berpangkat Wedono, gajinya bertambah menjadi Rp 45.000 per bulan.

Selain gaji, berdasarkan scene tersebut dapat ditarik makna bahwa aktivitas keseharian abdi dalem terhalang oleh aturan yang melarang mereka menempati bahkan menginjakan kaki di beberapa sudut ruangan Keraton, termasuk Bangsal Kencono. Aturan ini hingga kini terus berlanjut karena didasarkan dari kedudukan yang tercermin dari bangunan atap joglo berlantai tiga bahwa yang berhak untuk masuk ke Bangsal Kencono adalah raja dan keturunannya serta abdi dalem berdarah ningrat yang mempunyai gelar Kanjeng Raden Tumenggung (KRT). 
Kekuasaan raja diibaratkan sebagai "gung binathara, bau ndendha nyakrawati" (sebesar kekuasaan dewa, pemelihara hukum dan penguasa dunia). Binathara di sini dapat diartikan sebagai bahtara (dewa), artinya mempunyai kekuasaan seperti dewa, sehingga kekuasaan bersifat ilahiah. Begitu pula dengan pernyataan Moedjanto bahwa raja adalah "warana ing Allah" atau penjelmaan Tuhan. Oleh karena itu, kekuasaan raja bersifat mutlak sehingga konsekuensi ini mengharuskan rakyat selalu "nderek karsa dalem" (patuh pada kehendak raja) terhadap semua yang diputuskan raja (Basrowi, Sukidin, \& Suko, 2012)

Seperti yang tergambar pada video klip lagu "Teman Hidup," tampak abdi dalem yang menjalankan aktivitas kesehariannya dan mentaati aturan di Keraton Yogyakarta baik dalam berpakaian, maupun larangan memasuki ruangan tertentu, seperti Bangsal Kencono. Abdi dalem dengan penuh ketulusan mengabdi karena merasa terpanggil untuk mengabdikan dirinya pada Keraton dan Sultan.

Dalam konsep patronase, patron atau Sultan dianggap memberikan berkah atau ketenangan. Salah seorang abdi dalem bernama Mudiyono mengatakan bahwa la dan keluarga merasa dilimpahi berkah dari Tuhan Yang Maha Kuasa melalui Sultan. Itu terbukti dari usaha dagang serabutan yang lancar dan dua anaknya yang bisa lulus dari SMK di tengah pengabdiannya di Keraton Yogyakarta yang membawa berkah, (Kurniawan, 2014)

Melalui berkah tersebut, maka klien atau abdi dalem secara otomatis membalasnya dengan melakukan pengabdian dan dukungan kepada raja dan keraton, selain juga pengabdian ini didasari untuk kelestarian budaya Jawa. Di samping itu, kembali lagi pada kepercayaan masyarakat Jawa bahwa raja adalah penjelmaan dari Tuhan dan memiliki kekuasaan bagaikan dewa. Kepercayaan inilah yang meyakinkan abdi dalem untuk selalu dan lebih mantap untuk tetap mengabdi atau nderek karsa dalem (patuh) pada keraton.

Bagi orang awam, cerita Mudiyono memang tampak tak masuk akal karena tidak ada korelasinya antara mengabdi dengan keberkahan anaknya lulus SMK dan usaha yang lancar. Namun, nyatanya keyakinan ini telah tertanam kuat dalam diri masyarakat Jawa khususnya abdi dalem. Bagi mereka, ketika kebutuhan spiritual terpenuhi maka kebutuhan material akan mengikuti. Gaji tidak menjadi penghalang bagi abdi dalem untuk terus mengabdi pada Keraton dan Raja karena mereka yakin akan mendapat ketenangan dan keberkahan. Ada pula loyalitas primordial atau sesuku dari para klien atau abdi dalem berangkat dari rasa memiliki untuk bersama-sama melestarikan kebudayaan Jawa yang adiluhung.

Melalui kepercayaan terhadap raja dan nilai-nilai yang dianut oleh masyarakat Jawa maka terbentuklah suatu budaya yang terejawantahkan melalui simbolsimbol yang di dalamnya terdapat abdi dalem, dan keraton

Dari analisa diatas maka mitos yang terbentuk adalah relasi antara Keraton Yogyakarta dan abdi dalem adalah hubungan antara patron dan klien. Lirik lagu pada scene "Bersama arungi derasnya waktu" memperlihatkan hubungan akhrab antara Keraton dan abdi dalem yang sebenarnya saling bergantung. Keraton Yogyakarta tidak akan eksis hingga saat ini tanpa peran abdi dalem yang sejak dahulu hingga kini mengabdikan diri secara sepenuhnya kepada Keraton. Begitu pula dengan abdi dalem yang mendapat kebahagiaan dari Keraton Yogyakarta berupa ketenangan, kedekatan dengan raja dan keberkahan dalam kehidupan. Dalam proses representasi, hubungan 
antara patron dan klien nampaknya lebih menguntungkan salah satu pihak yaitu patron atau Keraton Yogyakarta dan cenderung mensubordinasi klien atau abdi dalem. Namun, dalam perspektif budaya Jawa, berbagai aturan dalam keraton justru dihayati dengan sepenuh hati oleh abdi dalem tanpa adanya rasa terpaksa. Mereka justru terpanggil untuk terus melestarikan budaya Jawa dan mempertahankan keistimewaan Yogyakarta sebagai pusat kebudayaan Jawa.

Berdasarkan paparan analisis di atas, maka budaya Jawa yang tergambarkan dalam video klip lagu "Teman Hidup" semakin mengukuhkan kekuasaan Keraton Yogyakarta dan kekuasaan tersebut sepenuhnya mendapat legitimasi atau dukungan dari abdi dalem.

\section{d. Mitos Relasi Kuasa dalam Budaya Jawa}

Video klip "Teman Hidup" merujuk pada dua bagian besar yaitu situasi di ranah domestik dan publik. Ranah domestic diwakilkan pada dua analisa mengenai relasi suami istri dan situasi dalam keluarga Jawa. Sedangkan pada ranah public digambarkan dalam profesi abdi dalem di Keraton Yogyakarta. Video klip ini membahas tentang kehidupan abdi dalem yang sehari-harinya bekerja di Keraton Yogyakarta. Selain bekerja sebagai abdi dalem, la berperan sebagai kepala rumah tangga dan hidup sederhana bersama dengan istri dan kedua anaknya.

Pada bagian yang pertama yaitu hubungan pasangan suami istri memperlihatkan kepatuhan istri terhadap suami. Ini bisa dilihat dari penghormatan yang dilakukan istri kepada suami ketika suami pergi bekerja maupun pada scene akhir ketika istri kembali membungkukan badan dan mencium tangan suami sambil mengucapkan terima kasih. Selain itu, tampak pula pembagian kerja diantara suami dan istri yang dianggap sebagai kodrat yang tidak dapat berubah. Suami berada pada sektor publik, istri berada dalam ranah domestik untuk mengurus rumah tangga.

Pembagian peran ini telah menempatkan perempuan sebagai pihak yang tersubordinasi. Di sini budaya patriarki yang mengakar kuat pada masyarakat Jawa telah menganggap bahwa perempuan adalah konco wingking. Peneliti melihat bahwa konsep konco wingking telah menggunakan analogi ajaran agama lewat kisah penciptaan untuk mensubordinasi perempuan. Lewat ajaran agama, di mana Hawa diciptakan setelah laki-laki dari tulang rusuk Adam memiliki makna bahwa posisi perempuan lebih rendah. Belum lagi perumpamaan swarga katut, neraka nunut seakan memberikan peringatan kepada istri untuk selalu patuh kepada suami.

Bagi perempuan Jawa, berada di ranah domestik dan tunduk kepada suami bukan berarti menjadi lebih rendah atau nomer dua. Pemaknaan budaya patriarki yang dianggap menjajah dalam budaya barat tidak berlaku sepenuhnya dalam budaya Jawa. Peran seorang istri justru menempatkannya sebagai penyeimbang. Istri dengan sikap tenang, dan lemah lembut tidak menunjukkan gejolak pemberontakan. Handayani dan Novianto (Handayani \& Novianto, 2005) menjelaskan wanita Jawa tidak perlu menjadi maskulin untuk mendapat kekuasaan. Sifat feminin yang dimiliki mampu membuatnya meraih kekuasaan yang diperoleh dalam diam dan tenang.

Pada bagian kedua, cengkeraman budaya patriarki tak berhenti sampai di situ, dalam scene yang memperlihatkan keluarga sedang makan bersama secara lesehan telah menunjukkan bahwa suami menjadi orang pertama yang menyantap makanan dibandingkan dengan istri dan anak. Setelah melayani suami, istri masih terus melayani anak-anaknya dengan mengambilkan piring dan sendok. 
Ungkapan yang menyatakan istri atau ibu adalah pusat rumah nampaknya tidak terjadi pada video klip ini. Jika ibu adalah pusat rumah, maka setelah memasak, la tak perlu melayani suami dan anakanaknya atau tidak perlu makan paling terakhir. Ini menunjukkan bahwa suamilah pemegang kekuasaan rumah yang sebenarnya karena la mendapat pelayanan, dan secara struktur sosial bertindak sebagai kepala rumah tangga.

Bagi perempuan Jawa, berada di ranah domestik dan tunduk kepada suami bukan berarti menjadi lebih rendah atau nomer dua. Pemaknaan budaya patriarki yang dianggap menjajah dalam budaya barat tidak berlaku sepenuhnya dalam budaya Jawa. Peran seorang istri justru menempatkannya sebagai penyeimbang. Istri dengan sikap tenang, dan lemah lembut tidak menunjukkan gejolak pemberontakan. Di sinilah seperti yang dikatakan oleh Handayani dan Novianto (Handayani \& Novianto, 2005) bahwa wanita Jawa tidak perlu menjadi maskulin untuk mendapat kekuasaan. Sifat feminin yang dimiliki mampu membuatnya meraih kekuasaan yang diperoleh dalam diam dan tenang.

Pada bagian ketiga yang membahas tentang abdi dalem dan Keraton Yogyakarta memperlihatkan hubungan yang saling tergantung antara abdi dalem dan Keraton Yogyakarta yang dapat diartikan sebagai hubungan antara patron dan klien. Dalam video klip lagu "Teman Hidup" tampak abdi dalem punakawan yang mengabdikan diri kepada keraton dengan sepenuh hati. Dari pengabdian ini, peneliti berpendapat bahwa telah terjadi ketidaksetaraan, di mana abdi dalem tidak menyadarinya dan cenderung menerima dengan alasan dan tujuan tertentu.

Abdi dalem atau klien mau melakukan apapun kepada patron atau keraton karena mereka percaya bahwa pengabdiannya akan mendapat ketenangan dan keberkahan. Keyakinan inilah yang membuat abdi dalem membalas kebaikan keraton dengan sifat loyal. Kesetiaan abdi dalem kepada keraton tak lepas dari kepercayaan masyarakat Jawa yang menganggap bahwa raja adalah titisan raja atau "gung binathara, bau ndendha nyakrawati" (sebesar kekuasaan dewa, pemelihara hukum dan penguasa dunia). Atas dasar inilah, maka abdi dalem akan nderek karsa dalem atau patuh pada kehendak raja

Di samping itu, kekuasan keraton Yogyakarta juga semakin nyata ketika tidak ada satu scene dalam video klip yang memperlihatkan sosok raja. Terlepas dari itu, kekuasaan keraton tetap terlihat melalui berbagai atribut dan aturan ketat yang membuat abdi dalem mendukung dan senantiasa menjaga keistimewaan Yogyakarta agar budaya Jawa tetap lestari di tengah modernisasi zaman. Peneliti melihat bahwa keistimewaan Yogyakarta dapat tetap terjaga karena jasa dari para abdi dalem yang secara optimal bekerja sebagai pengawal kebudayaan. Dalam budaya Jawa, menjadi pengawal bukan berarti berada pada posisi yang lebih rendah, melainkan ini dilakukan untuk menciptakan harmonisasi atau keselarsan sosial yang menjadi kunci utama dalam budaya Jawa.

\section{Kesimpulan}

Kesimpulan dalam penelitian ini bahwa Video klip lagu "Teman Hidup" Tulus mengukuhkan dominasi kuasa dalam budaya Jawa. Dominasi kuasa tersebut digambarkan dalam tiga bagian yaitu lewat relasi pasangan suami istri, suasana dalam keluarga dan hubungan antara Keraton Yogyakarta dan abdi dalem. Budaya Jawa melakoni hidup dalam harmonisasi, relasi dengan pasangan dan juga patron dilakukan dengan penuh keselarasan dan penerimaan peran. Namun dibalik itu semua ada nilai-nilai 
yang tersembunyi yaitu dalam relasi yang tidak seimbang dan cenderung mengukuhkan superioritas dan inferioritas.

\section{Referensi}

Barker, C. (2014). Kamus Kajian Budaya. Yogyakarta: Penerbit Kanisius.

Basrowi, Sukidin, \& Suko. (2012). Sosiologi Politik. Jakarta: Ghalia Indonesia.

Christomy, T., \& Untung. (2004). Semiotika Budaya. Depok: Pusat Penelitian Kemasyarakatan dan Budaya Direktorat Riset dan Pengabdian Masyarakat Universitas Indonesia.

Geertz, H. (1883). Keluarga Jawa. Jakarta: Penerbit Grafiti Pers.

Goode, W. J. (2002). Sosiologi Keluarga. Jakarta: Penerbit Bumi Aksara.

Griffin, E. (2012). A First Look At Communication Theory. Singapore: McGraw-Hill.

Hall, S. (1997). Representation : Cultural Representation and Sigifying Practices. England: Sage Publications.

Handayani, C. S., \& Novianto, A. (2005). Kuasa Wanita Jawa. Jakarta: PT LKIS Pelangi Aksara.

Hermawati, T. (2007). Budaya Jawa dan Kesetaraan Gender. Jurnal Komunikasi Massa Vol. 1. No. 1. Juli, 18-24.

Ida, R. (2014). Studi Media dan Kajian Budaya. Jakarta: Penerbit Prenada Media Group.

Kurniawan, A. B. (2014). Keinginan untuk "Ngalap Berkah.". Diakses tanggal 6 Desember 2016: 10 Januari http://print.kompas.com/baca/2014/ 01/10/Keinginan-Ngalap- $\quad \mathrm{X} \% 2 \mathrm{C}-$ Berkah.
Moedjanto. (1994). Kasultanan Yogyakarta dan Kadipaten Pakualam. Yogyakarta: Penerbit Kanisius.

Priambodo, A. (Selasa 17 Mei 2016 ). Lewat Kunci Hati, Afgan Perkenalkan Album Terbarunya. Jakarta: https://celebrity.okezone.com/read/ 2016/05/17/205/1390765/lewatkunci-hati-afgan-perkenalkanalbum-terbarunya.

Rachmadiana, M. (2004). Mencium Tangan, Membungkukkan Badan, Etos Budaya Sunda, Yogyakarta, Madura. Yogyakarta. Humanitas: Indonesian Psychologycal Journal Universitas Ahmad Dahlan Vol.1 No.2 Agustus, 33-44.

Rama, A. P. (2007). Kebudayaan Jawa: Ragam Kehidupan Kraton dan Masyarakat di Jawa 1222 - 1998. Yogyakarta: Cahaya Ningrat.

Rudiana, P. A. (2016). Abdi Dalem Keraton Yogya Dapat Gaji dan Honor dari Negara.

https://m.tempo.co/read/news/2016 /04/24/058765333/abdi- dalemkeraton- yogya-dapat-gaji-danhonor-dari-negara Diakses tanggal 4 Januari 2017.

Siswanto, D. (2010). Pengaruh Pandangan Hidup Masyarakat Jawa Terhadap Model Kepemimpinan. Jurnal Filsafat Vol. 20, Nomor 3, Desember Universitas Gadjah Mada.

Strinati, D. (2009). Popular Culture : Pengantar Menuju Teori Budaya Populer. Yogyakarta: AR-Ruzz Media Group.

Suseno, F. M. (1984). Etika Jawa: Sebuah Analisa Falsafi Tentang Kebijaksanaan Hidup Jawa. Jakarta: PT Gramedia.

Wardani, L. K. (2011). Gaya Seni HinduJawa Pada Tata Ruang Keraton 
Yogyakarta. Dimensi Interior, Vol. 9, No. 2, Desember, 108-118.

Wibowo, Supanto, Pramono, \& Moeljono. (1990). Pakaian Adat Tradisional Daerah Istimewa Yogyakarta. Jakarta: Departemen Pendidikan dan Kebudayaan. 